\title{
Institute of Plea Bargain: Features of Legal Regulation
}

\author{
Olga S. Demko ${ }^{1}$, Valerya N. Kolesnikova ${ }^{1}$, Gennadij Yu. Lesnikov ${ }^{1}$, Lyudmila A. Malimon ${ }^{1} \&$ Lyudmila A. \\ Spektor $^{2}$ \\ ${ }^{1}$ Belgorod State University, 85 Pobedy Street, Belgorod, the Belgorod region, Russia \\ ${ }^{2}$ The Institute of service sector and entrepreneurship (branch) of DSTU in Shakhty, 147 Shevchenko street, \\ Shakhty, Rostov oblast, Russia \\ Correspondence: Olga S. Demko, Belgorod State University, 85 Pobedy Street, Belgorod, the Belgorod region, \\ 308015, Russia. E-mail: russia@prescopus.com
}

Received: June 19, 2017

doi:10.5539/jpl.v10n4p187
Accepted: July 18, $2017 \quad$ Online Published: August 30, 2017

URL: https://doi.org/10.5539/jpl.v10n4p187

\begin{abstract}
The analysis of plea bargain criminal procedural institute in the prism of its legislative regulation development was carried out. It was concluded that the term "plea bargain" is expressed legally in the terms "agreement on pleading guilty", "the confession of guilt", "plea bargain", "request of one of the parties", "pre-trial cooperation agreement", and "conclusion of an agreement". With the legalization of the plea bargain institution, a sovereign approach is presented by the individual countries of North America, Europe, the post-Soviet space, based on legal and social realities.
\end{abstract}

Keywords: legislative regulation, plea bargain, pleading guilty agreement, cooperation agreement

\section{Introduction}

The goal of modern criminal and criminal procedure legislation of most countries is not only the restoration of justice by punishing the individuals responsible for the crimes, but also the development of measures aimed at criminal phenomenon prevention. One such measure is the institution of a deal with justice, which determines the possibility of obtaining lesser sentences by suspects or accused ones than prescribed by law, as the result of cooperation with the prosecution or the court. The order of conciliation proceeding application is determined by the criminal procedure legislation of the countries in North America (USA), Europe (France, Italy), the post-Soviet space (Estonia, Kazakhstan, Belarus, Russia). However, it should be noted that the definition of a "plea bargain" is an exceptionally collective, doctrinal term, since the presented wording does not appear in the legislation of the studied countries. Summarizing the world norm-setting practice of transaction with justice, it can be concluded that it exists in two forms usually: a plea bargain and an agreement on cooperation.

In this regard, the purpose of this study is to compare the provisions of the criminal procedure legislation in the countries of North America, Europe, and the post-Soviet space, reflecting the terminological variation of transactions with justice, and to study the specific approach of each country to the issue of conciliation proceeding regulation.

\section{Methodology}

In the process of research, general scientific (system, analysis, and synthesis, logical) and private scientific (historical-legal, comparative legal, formal-legal, formal-logical) methods were used that made it possible to present the legal phenomenon under study comprehensively.

\section{Discussion and Results}

The spread of legal forms of transactions with justice began in an Anglo-Saxon legal family. Directly the very term "a plea bargain" in its modern legal understanding appeared in the United States during late XIX-th century.

Currently, the federal rules of criminal justice, adopted by the US Supreme Court and entered into force on March 21, 1946, contain the main provisions on the procedure of conciliation proceeding application. In particular, Rule 11 is called "Pleas", the text of which has another term "Plea Agreement", that is the "agreement on guilt confession", therefore it should be considered a legal interpretation of the doctrinal concept "a plea bargain" (Federal Rules of Criminal Procedure in USA, 1946). 
However, in law enforcement practice and the criminal procedural doctrine of the United States another concept is used often - "Plea Bargaining" (a plea bargain). For example, the US Supreme Court in the case of In Santobello v. New York (1971) used this term in the court decision (In Santobello v. New York, 1971). The analysis of Rule 11 provisions made it possible to determine that, depending on the volume of obligations assumed by the defense a plea guilty agreement can be achieved in the following forms: "Guilty Plea" and "Nolo Contendere Plea" (Federal Rules of Criminal Procedure in the USA, 1946). The main distinguishing feature of these forms of agreements is that the suspect in the first case, the accused one pleads guilty. The result of which is the conviction issued by the court without trial, which the defense cannot appeal later. With the application of "Nolo Contendere Plea", the suspect, the accused one does not admit his guilt, and he does not dispute the prosecution arguments about the guilt in committed crime. In this case, the defense may appeal the sentence (Ivanov, 2012, p. 283). Case law contributed to the emergence of another form of agreement - "Alford plea", which was named after the case "North Carolina v. Alford" (1970). The essence of such an agreement is that, if a defense recognizes his guilt, he retains the right to challenge the prosecution arguments in the courts of the first instance and at the court of appeal (North Carolina v. Alford, 1970).

In our view, a significant drawback of the US conciliation procedure is the negative legal consequences for an applicant, consisting in his automatic waiver of constitutional rights (for example, the right to a trial by a jury), and the absence of such a process stage as a trial (Dervan, 2012, p. 60).

The Institute of a plea bargain has a legislative interpretation in Section 8 of the French Criminal Procedure Code of 1959 and it is called "De la comparition sur contraissance prealable de culpabilite", that is "the confession of guilt". Structurally the section consists of 11 articles (from 495-7 to 495-16). In France as in the United States, an agreement can be concluded in two versions: between a prosecutor and a suspect (an accused one) who pleaded guilty and only in the cases of minor offenses, and between a prosecutor and the person who made a preliminary statement of a plea that is subjected to mandatory approval by a court. The last form of an agreement is applicable only if a person committed a crime for which the maximum sentence makes five years (Code de procedure penale en France, 1959). Unlike the American model a plea bargain in France cannot be concluded with a person under the age of 18 , as well as with a person who committed serious crimes against a person (a murder), violent and sexual crimes, as well as other crimes, the commission of which provides the imprisonment for more than 5 years according to law (Article 495-7, Article 495-16 of the Criminal Procedure Code of France). Nevertheless, the conclusion of a deal encourages less severe punishment like in the US.

In the current legislation of Italy, the deal with justice in its own legal interpretation is recorded in the CPC of 1989: in the title II "The application of punishment at the request of one of the parties" (Titolo II, Applicazione della pena su richiesta delleparti) (Codice di procedura penale, Italia). However, you can find another term in the criminal procedural literature of Italy - "patteggiamento", that is "an agreement on guilt confession" (Francesca et al.). Such an agreement is made between the prosecution and the defense like in France and the US, but it does not imply the change in a charge nature, but concerns only a punishment and its volume - it is directly proportional to a guilty plea and an agreement between the prosecution and the defense. Under the second form of a deal, abbreviato, the agreement with the defendant is not concluded, and the case is considered at the preliminary hearing on minor criminal cases. The sentence is decided by the court on the basis of the evidence available in a criminal case. With the consent of an accused one to this form of reduced proceeding, the punishment for a crime is reduced at least by one-third of the main punishment (Codice di procedura penale, Italia).

Like most countries of the world where the institution of a plea bargain is applied, the criminal procedural legislation of the Republic of Kazakhstan has recorded the institution of the procedural agreement in two forms: "konnyi moyyndau tourami məmile" (a plea bargain) and "тыntymātasty" tourals kelisim (a cooperation agreement). So, a plea bargain is for the crimes of small or medium gravity and for grave crimes in cases where a suspect (an accused one) agrees with a suspicion (a charge). An agreement can be concluded on the initiative of a suspect, an accused, a defendant, a defender or a prosecutor at any stage of a criminal process up to a court removal to an advisory room (Қазақстан Республикасының Қылмыстық-процестік кодексі, 2014).

A procedural cooperation agreement (the second form of conciliation proceedings) can be concluded for all categories of crimes, including particularly serious crimes, extremist and terrorist crimes, as well as the acts committed by a criminal group. This institution is radically different from a plea bargain in the legislation of the studied countries. For example, in addition to a suspect, an accused, a defendant, a convicted person can also apply about his imprisonment. Thus, an agreement can be reached in the process of a criminal case proceeding until the execution of a sentence. Also, an important distinctive feature of the Kazakh conciliation process is the mandatory conduct of an investigation until the moment of a guilt determination and all the circumstances of a 
committed crime (Regulatory resolution of the Supreme Court of the Republic of Kazakhstan, 2016).

The criminal procedure legislation of some countries does not provide for the variation of transactions with justice, therefore, only one form of conciliation proceedings is applied. Estonia should be attributed to such countries, where the so-called institution of a plea bargain is designated as "Kokkuleppemenetlus" (the conclusion of an agreement). A normatively investigated criminal procedural institution is regulated by Section 2 of the Estonian Criminal Procedure Code of 2003 (articles 239-250). Conciliation proceedings in Estonia are carried out in only one procedural form - when an agreement is reached between a prosecutor and a defense, and it should be noted that the initiative of such an agreement conclusion can come from both parts. The initiation of conciliation proceedings is also possible within the framework of a trial, up to a court removal to an advisory room (Kriminaalmenetluse seadustik, Eesti, 2003). It is impossible to conclude a deal with a person who committed a grave or especially serious crime in Estonia as in France and Italy.

In the Republic of Belarus, the institution of a pre-trial cooperation agreement appeared relatively recently, namely with the adoption of the relevant Law in January 2015. In Section XIV of the Criminal Procedure Code of the Republic of Belarus (1999), which provides for the details of proceeding in certain categories of criminal cases, a new chapter 49-1 "Proceeding of a criminal case against a suspect (an accused one) with whom a pre-trial cooperation agreement was concluded" (Article 468-5 - 468-12 of the RB Criminal Procedure Code). As in other countries with conciliation proceedings, a pretrial agreement can be concluded only on the basis of a suspect (an accused) request, which is submitted in writing to a prosecutor. It can be declared after the initiation of a criminal case and before the end of a preliminary investigation. It should be noted that the law establishes the possibility of a pre-trial cooperation agreement conclusion for minor offences, provided that an application is signed by its legal representative (The criminal-procedural code of the Republic of Belarus, 1999).

In Russia, an analyzed institution is named as a pre-trial cooperation agreement, which appeared as the result of Chapter 40.1 of RF Criminal Procedure Code enactment by the Federal Law No. 141-FL issued on June 29, 2009 (Federal Law, 2009).

It should be noted that the criminal procedure legislation of most foreign countries provides the possibility of a conciliation deal conclusion up to a court removal to an advisory room, and in some countries (Kazakhstan) until the execution of a sentence. Directly from the very name of a Russian institute one can determine that an agreement on cooperation cannot be achieved during the judicial stages. According to Part 2 of the Art. 317.1 of RF CCP, a suspect or an accused one has the right to file a petition for a pre-trial cooperative agreement from the moment of a criminal investigation beginning until the announcement of a preliminary investigation completion, that is, before an indictment is drawn up by an investigator (The Criminal Procedure Code of Russian Federation, 2001). When this institution was introduced into the Russian criminal process, a legislator pursued the goal of struggle with an organized crime, extremist crimes, and the acts associated with the creation of stable criminal communities (Explanatory note "To the federal law draft "On Amendments to the Criminal Procedure Code of Russian Federation). Therefore, the possibility of a pre-trial cooperation agreement conclusion is possible only within a preliminary investigation. The use of this institution is excluded on the form of an inquiry. A similar provision contains the CCP of the Republic of Belarus. A legislator's restrictions regarding the application of a pre-trial agreement after in the framework of an inquiry cause disputes in the scientific literature nowadays (Novikov, 2013, p. 44). This problem was not resolved by the Resolution of RF Supreme Court Plenum "About the application practice of special procedures for the hearing of criminal cases by the courts at the conclusion of a pre-trial cooperation agreement" held on June 28, 2012.

Contentious proceedings can be initiated by a written request of a suspect or an accused one, filed to a prosecutor. In the course of the study, we found that in the vast majority of countries where conciliation proceedings are applied, a prosecutor may also be a deal conclusion initiator. However, Russian law does not provide such a provision, establishing only a prosecutor's right to conclude a pre-trial cooperation agreement (Part 5, Article 21 of the Criminal Procedure Code) (The Criminal Procedure Code of Russian Federation, 2001). In our opinion, it would be logical to envisage the right to conclude a pre-trial cooperation agreement as an independent item by the Art. 46, 47, defining a legal status of a suspect and an accused one. During the explanation of the rights and duties to a suspect, an accused one by an investigator, these participants of the proceedings will know and understand initially the possibilities and legal consequences of conciliation proceedings. Perhaps this will lead to a more successful interaction between the prosecution and the defense. The second option of this problem solution may be a prosecutor's or an investigator's legislative power consolidation concerning the possibility of a pre-trial cooperation agreement achievement (Sarkisyants, 2012, p. 47).

Chapter 40.1 of RF Criminal Code also does not contain any provisions on the conciliation proceedings 
application possibility or prohibition against minors. As was stated above, this possibility is envisaged with the mandatory participation of a minor legal representative in the Criminal Procedure Code of the Republic of Belarus. Because of the lack of a legally enforceable right of a minor to conclude a pre-trial cooperation agreement the Plenum of the Supreme Court indicated that the provisions of Chapter 40.1 of the RF Criminal Procedure Code are not applied to suspects or accused one who were under the age of eighteen by the time of a crime commission.

Also, as a rule, the above-mentioned analysis of the law made it possible to establish that the deals with justice, can consist solely of small and medium gravity crimes, but in no way for grave and especially grave crimes (France, Estonia). There are no restrictions on the application of a studied criminal justice institution by the criterion of a committed crime gravity in Russia (as in Belarus and Kazakhstan).

\section{Conclusions}

Summarizing the experience of a criminal procedural institution legislative regulation concerning a deal with justice in a number of countries of North America, Europe, the post-Soviet space, there are reasons to conclude the following:

1) The concept of a "deal with justice" is doctrinal and collective one, which was not recorded in this formulation within the criminal procedural legislation of the studied group of countries.

Legislatively, so-called "deal with justice" is expressed in the definitions of "a plea agreement" (US), "the confession of guilt" (France), "a request of one of the parties" (Italy), "a plea bargain" (Kazakhstan), "a pre-trial cooperation agreement" (Russia, the Republic of Belarus) and "the conclusion of an agreement" (Estonia).

The term "plea bargain (agreement)" is the most capacious and general, in our opinion. It is applied in the countries where an agreement can be concluded up to the removal of a court to an advisory room. This concept can be accurately added with the doctrinal term "a deal with justice", since an agreement can be concluded during judicial stages. The application of the term "a deal with justice" to the term "a pre-trial cooperation agreement" applied in the criminal procedure legislation of Russia and the Republic of Belarus is not entirely correct in our opinion, since an agreement is possible only at a preliminary investigation stage. In this regard, we believe that the use of the term "a deal with the investigation" is appropriate in this case. It should also be noted that the concept of "a pre-trial cooperation agreement" is more precise, since one can determine directly from the name itself that the conclusion of a transaction is impossible during the judicial stages of a process.

2) The majority of the studied countries apply a differentiated (usually, two-species one) system of transactions with justice, determined according to various criteria: depending on the volume of commitments undertaken by the defense (USA); depending on the category of a crime committed (France, Kazakhstan); depending on a punishment applied (Italy).

Only one form of the transaction is applied in Estonia, Russia and in the Republic of Belarus - the conclusion of an agreement between the prosecution and the defense.

3) In a number of countries (France, Italy, Estonia), the institution of a transaction with justice cannot be applied to persons who have committed serious and particularly serious crimes. In the United States, the Republic of Belarus, Russian Federation the application of this institution for these categories of crimes is possible on the contrary. The Republic of Kazakhstan during the determination of the legal forms of a deal with justice determined the severity of a committed crime as a criterion.

\section{References}

Code de procedure penale en France. (1959, March 2). Retrieved from https://www.legifrance.gouv.fr/affichCode.do?cidTexte=LEGITEXT000006071154

Codice di procedura penale, Italia. (1988, September 22). Retrieved from http://www.studiocataldi.it/codiceprocedurapenale/codice-procedura-penale.pdf

Dervan, L. E. (2012). Bargained Justice: Plea Bargaining's Innocence Problem and the Brady Safety-Valve. Utah Law Review, 51-97.

Explanatory note "To the federal law draft "On Amendments to the Criminal Procedure Code of Russian Federation (on the issue of pre-trial cooperation agreement order improvement)". (2017, May 7). Retrieved from http://asozd.duma.gov.ru

Federal Rules of Criminal Procedure in USA. (1946, March 21). Retrieved from https://www.law.cornell.edu/rules/frcrmp 
Francesca Romanelli, Silvia Vagnoni e, Enrico Leo Il patteggiamento: l'applicazione della pena su richiesta delle parti. (n.d.).

Retrieved

from

http://www.studiocataldi.it/guide_legali/guide-procedura-penale/patteggiamento.asp

In Santobello v. New York, 404 U.S. 257, 260, 92 S.Ct. 495, 498, 30 L.Ed.2d 427. (1971). Retrieved from https://supreme.justia.com/cases/federal/us/404/257/

Kriminaalmenetluse seadustik, Eesti. (2003). Retrieved from https://www.riigiteataja.ee/akt/KrMS

North Carolina v. Alford, 400 U.S. 25, 35 -36 n. 8, 91 S.Ct. 160, 27 L.Ed.2d 162. (1970). Retrieved from https://ru.scribd.com/document/310831357/North-Carolina-v-Alford-400-U-S-25-1970

\section{Copyrights}

Copyright for this article is retained by the author(s), with first publication rights granted to the journal.

This is an open-access article distributed under the terms and conditions of the Creative Commons Attribution license (http://creativecommons.org/licenses/by/4.0/). 